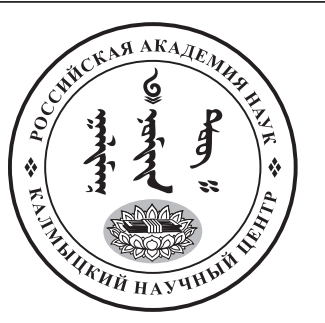

Published in the Russian Federation

Oriental Studies (Previous Name: Bulletin of the Kalmyk Institute

for Humanities of the Russian Academy of Sciences)

Has been issued as a journal since 2008

ISSN: 2619-0990; E-ISSN: 2619-1008

Vol. 14, Is. 4, pp. 825-833, 2021

Journal homepage: https://kigiran.elpub.ru

УДК / UDC 811.512.37’373:39

DOI: $10.22162 / 2619-0990-2021-56-4-825-833$

\title{
Сравнительное исследование лексики в современном калмыцком языке и языке ойратов Монголии в разделе «традиционное жилище и его части»
}

Светлана Менкеновна Трофимова ${ }^{1}$ Баярма Дашидондоковна Бальжинимаева ${ }^{2}$, Валентина Лиджиевна Боктаева ${ }^{3}$ Бямбажав Тувшинтогс ${ }^{4}$

${ }^{1}$ Калмыцкий государственный университет им. Б. Б. Городовикова (д. 11, ул. А. С. Пушкина, 358000 Элиста, Российская Федерация)

доктор филологических наук, профессор

iD 0000-0003-1812-7117. E-mail: trofimovasm@mail.ru

2 Бурятский государственный университет им. Д. Банзарова (д. 24а, ул. Смолина, 670000 Улан-Удэ Российская Федерация)

кандидат филологических наук, доцент, заведующий кафедрой

iD 0000-0001-6852-7835.E-mail: bairka2002@list.ru

${ }^{3}$ Калмыцкий государственный университет им. Б. Б. Городовикова (д. 11, ул. А. С. Пушкина, 358000 Элиста, Российская Федерация)

кандидат педагогических наук, доцент

iD 0000-0002-4471-5804.E-mail: valid25@yandex.ru

${ }^{4}$ Монгольский государственный университет (д. 3, Бага-Тойруу, 210648 Улан-Батор, Монголия) кандидат филологических наук, доцент, заведующий кафедрой

iD 0000-0001-6884-7951. E-mail: altaicamon@yahoo.com

(C) КалмНЦ РАН, 2021

(C) Трофимова С. М., Бальжинимаева Б. Б., Боктаева В. Л., Тувшинтогс Б., 2021

Аннотация. Целью настоящего исследования ставилось введение в научный оборот и анализ в сравнительном и сравнительно-историческом аспектах названий традиционного жилища и его частей в современном калмыцком языке и в языке ойратов Монголии. Для сравнения привлекался материал из старописьменного монгольского, халха-монгольского и бурятского языков на предмет выявления общих терминов и установления их общемонгольской основы, а также выявлялись особенности ойратского ареала и специфические черты, характерные для калмыцкого языка и языка ойратов Монголии, которые отображают реальную историческую действительность данных этносов как в период общемонгольского праязыка, так и во время расселения монгольских племен и образования монгольских языков. Maтериаль и методы. 
Материалом исследования послужили данные словарей привлекаемых языков, а также полевые записи, собранные у информантов во время экспедиций к ойратским племенам в Западную Монголию. Основные методы исследования - описательный, сравнительный, сравнительно-исторический метод, метод сплошной выборки. Результаты. Проведенный анализ позволил выявить общемонгольские и специфические термины, характерные для калмыцкого языка и языка ойратов Монголии. В результате изучения собранного материала авторы приходят к выводу о единстве лексики традиционного жилища и его частей в калмыцком языке и языке ойратов Монголии, что свидетельствует о единых истоках и большой древности самобытной материальной культуры ойратских племен.

Ключевые слова: общемонгольская лексика, жилище, названия частей жилища, калмыцкий язык, язык ойратов Монголии, халха-монгольский язык, бурятский язык, старописьменный монгольский язык

Благодарность. Исследование выполнено при финансовой поддержке РФФИ в рамках научного проекта №19-512-44006 «Взаимодействие языков в поликультурном пространстве на материале монгольских языков: сравнительный анализ калмыцкого языка, языка ойратов Монголии и бурятского языка».

Для цитирования: Трофимова С. М., Бальжинимаева Б. Б., Боктаева В. Л., Тувшинтогс Б. Сравнительное исследование лексики в современном калмыцком языке и языке ойратов Монголии в разделе «традиционное жилище и его части» // Oriental Studies. 2021. Т. 14. № 4. C. 825-833. DOI: 10.22162/2619-0990-2021-56-4-825-833

\title{
Traditional Dwelling and Its Parts in Modern Kalmyk (Russia) and Oirat (Mongolia): A Comparative Study of Vocabularies
}

\author{
Svetlana M. Trofimova1, Bayarma D. Balzhinimaeva², Valentina L. Boktaeva ${ }^{3}$, \\ Byambajav Tuvshintogs ${ }^{4}$
}

${ }^{1}$ Gorodovikov Kalmyk State University (11, Pushkin St., 358000 Elista, Russian Federation) Dr. Sc. (Philology), Professor

(iD 0000-0003-1812-7117.E-mail: trofimovasm@mail.ru

${ }^{2}$ Banzarov Buryat State University (24A, Smolin St., 670000 Ulan-Ude, Russian Federation) Cand. Sc. (Philology), Associate Professor, Head of Department

(iD)0000-0001-6852-7835. E-mail: bairka2002@list.ru

${ }^{3}$ Gorodovikov Kalmyk State University (11, Pushkin St., 358000 Elista, Russian Federation) Cand. Sc (Pedagogy), Associate Professor

iD)0000-0002-4471-5804.E-mail: valid25@yandex.ru

${ }^{4}$ National University of Mongolia (3, Baga Toiruu, 210648 Ulaanbaatar, Mongolia)

Cand. Sc. (Philology), Associate Professor, Head of Department

(iD)0000-0001-6884-7951. E-mail: altaicamon@yahoo.com

(C) KalmSC RAS, 2021

(C) Trofimova S. M., Balzhinimaeva B. B., Boktaeva V. L., Tuvshintogs B., 2021

\begin{abstract}
Introduction. The article aims at studying the terms for the traditional dwelling and its parts in the modern Kalmyk language and in the language of the Oirats of Mongolia in a comparative and comparative-historical modes. Analysis of lexical material of the old-written Mongolian, the KhalkhaMongolian, and the Buryat languages helped identify common terms and common Mongolian basis; also, some features of the Oirat distribution area and specific characteristics of Kalmyk and Oirat of Mongolia were clarified. The lexical material reflects to a degree the historical realities of the ethnic groups in the period of the common Mongolian proto-language, and in a later period of the settlement of Mongolian clans and the formation of Mongolian languages. Materials and methods. The research
\end{abstract}


database comprises the data of dictionaries of the languages under study, as well as field material collected from informants during expeditions to Oirat groups in Western Mongolia. The main research methods are descriptive, comparative, comparative-historical, and continuous sampling. Results. The analysis helped identify both common Mongolian and specific terms characteristic of Kalmyk and Oirat of Mongolia, reflecting the nomadic lifestyle of pastoralists. Conclusion. The authors argue that the commonality of the traditional dwelling vocabulary in the languages in question indicates their common origin, as well as great antiquity of the Oirat clans' original material culture.

Keywords: common Mongolian vocabulary, dwelling, names of parts of a dwelling, Kalmyk language, Oirat language of Mongolia, Khalkha-Mongolian language, Buryat language, old-written Mongolian language

Acknowledgements. The reported study was funded by RFFR, project no. 19-512-44006 'Interaction of Languages in Multicultural Environment (Mongolic Languages): Comparative Analyses of Kalmyk, Oirat (Mongolia) and Buryat'.

For citation: Trofimova S. M., Balzhinimaeva B. B., Boktaeva V. L., Tuvshintogs B. Traditional Dwelling and Its Parts in Modern Kalmyk (Russia) and Oirat (Mongolia): A Comparative Study of Vocabularies. Oriental Studies. 2021. Vol. 14 (4): 825-833. DOI: 10.22162/2619-0990-2021-56-4825-833

\section{है}

\section{Введение}

Письменный язык ойратов не отражал их живую речь, несмотря на то, что уже в XIII в. они имели свой разговорный язык. Научное монголоведение, как известно, зарождается в первой половине XIX в. в трудах Якова Шмидта, Александра и Алексея Бобровниковых, Александра Попова [Шмидт 1832; Бобровников 1835; Попов 1847; Бобровников 1849] и др., в которых описываются классический старописьменный монгольский язык на древнеуйгурской основе и калмыцкий язык на «тодо бичиг» («ясном письме»), созданный ойратским просветителем Зая-пандитой в середине XVII в.

В XX в. проводится работа по унификации языков для калмыков, бурят и монголов (халхов), в результате чего была введена кириллица. Монгольские народы Внутренней Монголии до сих пор используют на письме старописьменную монгольскую графическую систему, а ойратские племена, проживающие на территории Синьцзяна (КНР), — «ясное письмо». К сожалению, ойратские племена, проживающие в Западной Монголии, не имеют своей письменности и используют во всех сферах своей деятельности современный монгольский литературный язык на кириллице.

Большую актуальность имеет изучение лексического строя языков в сравнительном и сравнительно-историческом аспекте, это имеет немаловажное научное значение для развития монгольских языков и позволит создать научную базу для написания исторических грамматик монгольских языков.

Что касается современного калмыцкого языка и его говоров, то они относительно хорошо изучены для того, чтобы начать сравнительно-историческое изучение. Данное исследование выполнено совместно с монгольскими партнерами в рамках научного проекта - при поддержке Российского фонда фундаментальных исследований и Министерства образования и науки Монголии. Исследование представляется актуальным и ставит своей целью установить как общие черты, так и своеобразные черты между калмыцким языком и языком ойратов Монголии.

Путем сравнения элементов лексического состава калмыцкого языка с языком ойратов Монголии выявлено, что в этих языках сохраняется общемонгольский языковой пласт и общеойратские ареальные черты в лексическом строе [Рассадин, Трофимова, Шагдарсурэн, Болд, Даваасурэн 2010: 166-167]. В работе в соответствии с целью и ее задачами используется фактический материал из словарей по анализируемым языкам, полевой материал по ойратским диалектам, собранный во время поездок в Западную Монголию, и личные наблюдения авторов данной статьи. 
Отдельные сведения по терминам традиционного жилища приводятся в работах [Эрдниев 1970; Эрендженов 1990; Пюрбеев 1996]. В этом ряду необходимо отметить работу на данную тему В. И. Рассадина и др. [Рассадин, Трофимова, Чулуунбаатар 2017]. Можно отметить близкие по тематике нашего исследования работы [Мазарчук 2017; Трофимова, Даваасурэн 2017; Бальжинимаева 2006; Бальжинимаева 2018].

Материалы и методы исследования

Фактический материал исследования методом сплошной выборки производился из словарей [БАМРС, 1 2001; БАМРС, 2 2001; БАМРС, 3 2001; БАМРС, 4 2002; Шагдаров, Черемисов, I 2010; Шагдаров, Черемисов, II 2010; КРС 1977; Пюрбеев 1996], а также использовались полевые записи, собранные у информантов во время поездок к западным монголам.

\section{Анализ лексико-семантической груп- пы «жилище и его части»}

Традиционным жилищем монголоязычных народов была войлочная юрта: калм., ойр.М. ишкә гер (х.-монг. эсгий гэр, бур. hэеbl гэр), стпм. isegei ger [КРС 1977: 138; ПМА 2018; БАМРС, 1: 481; Шагдаров, Черемисов, II: 582], которая впервые упоминается в китайском источнике «Исторические записки» Сыма Цяня: в 629 г. до н. э. на востоке монгольские племена до хуннского периода жили в жилищах, имеющих форму шатра [Материалы по истории 1968: 142-143]. Кроме этого, в заметках средневековых путешественников сообщается еще об одном виде жилья под названием гэрт тэрэг 'юрта-телега'. Кочевка с такими юртами-телегами, по мнению авторов заметок, выглядит величественно [Материалы по истории 1968: 142].

\section{Названия, связанные с жилищем}

Общим названием для современного калмыцкого языка и языка ойратов Монголии является: калм., ойр.М гер (х.-монг., бур. гэр), стпм. ger 'дом'. Поскольку ойратские племена, как и все монгольские народы, вели кочевой, а позже некоторые из них сменили на полукочевой образ жизни, то в их языках имеются разные названия жилища, которые отличаются формой и материалом, например: калм., ойр.М ишкә гер (х.-монг. эсгий гэр, бур. hэеы гэр), стпм. isegei ger 'войлочная юрта, юрта скотовода-кочевника';

калм., ойр.М модн гер (х.-монг. модон гэр, бур. модон гэр), стпм. modun ger 'деревянная изба, бревенчатый дом';

калм., ойр.М чолун гер (х.-монг. чулуун гэр, бур. шулуун гэр), стпм. čilaүun ger 'каменный дом' [КРС 1977: 138; ПМА 2018; БАМРС, 1: 481; Шагдаров, Черемисов, I: 240].

По внешнему виду традиционного жилища гер можно определить имущественное благосостояние хозяина. Так, например, иаһан гер 'белый дом' был покрыт белой кошмой, принадлежал богачам, священникам или новобрачным. Подавляющее большинство семей имело хар гер 'черный дом', поскольку кошма, которой покрывалось традиционное жилище, с течением времени становилась закопченной и изнашивалась [КРС 1977: 138; ПМА 2018; БАМРС, 1: 481; Шагдаров, Черемисов, I: 240]. Многим беднякам приходилось жить в особом конусообразном гер, для обозначения этого понятия в анализируемых языках имеется несколько названий:

калм., ойр.М жслмм 'жоломейка (без решетчатых стенок), юрта из жердей и кошмы' (х.-монг. жолом), в бурятском языке этот термин не зафиксирован, стпм. jolom- $a$ 'жоломейка', юрта из жердей и кошмы без решетчатых стен';

калм., ойр.М уури 'хижина, лачуга'; (х.монг. урu, бур. урс), стпм. игис́а 1) 'хижина; шалаш, остроконечный конический шалаш из кольев, крытый берестой': хаанд ордон, хариад ури 'хану - дворец, простолюдину - хижина; всякой скотине свой хлев'; 2) 'балаган';

калм., ойр.М деглә гер 'юрта, кибитка (без дымового отверстия)' [КРС 1977: 138].

Названия, связанные с частями жилимиа

Материал исследования показывает, что основные части традиционного жилища степняков-кочевников состоят из следующих терминов-наименований.

Калмыки и ойраты решётчатую стену своей кибитки называют терм, которая обычно состоит из шести-восьми складных решеток (терм), например: нәәмн термтә хальмг ишкә гер 'восьмистенная войлоч- 
ная калмыцкая юрта’. В калмыцком эпосе «Джангар» встречаются гиперболизированные описания, например, дөчн дөрвн термтә, дөрвн миңгн уньта ияаһан өргә 'большая белая юрта-дворец с сорока четырьмя решетчатыми стенами, с четырьмя тысячами жердей' (см.: [КРС 1977: 495-496]. Халха-монголы и буряты решетчатую стену называют: х.-монг. хана(н) '1) решетчатая стенка юрты; арван таван толгойтой хана 'решетчатая стенка юрты с пятнадцатью головками (верхними концами ван $x a$ натай гэр 'пятистенная юрта'; 2) решетка на стене здания для штукатурки; 3) стена; 4) мишень [БАМРС, 4 2002: 36]; бур. хана 'стена, стенка', hэые гэрэй хана 'решетчатая стенка юрты'; арбан табан тархитай хана 'решетчатая стенка с пятнадцатью головками (верхними рогульками, которых в одной стенке насчитывалось 13-15 штук)' [Шагдаров, Черемисов, II 2010: 393], стпм. qan-a .

Бурятский материал показал, что решетчатые стены традиционного жилища бывают трех видов: 1) зайдан хана 'открытая стенка' (расстояние между просверленными в нескольких местах на одной палке дырочками - примерно 14-15 см), обычно в таких юртах с открытой стеной жила прислуга [Бальжинимаева 2006: 17]; 2) түлгэ хана 'досл.: стенка-баран-двухлеток' (расстояние между дырочками на стенной палке - около 10 см) [Бальжинимаева 2006: 17]; 3) хурьган хана 'досл. стенка-ягненок' (расстояние между дырочками - 6-7 см), в таких юртах жили зажиточные люди [Бальжинимаева 2006: 17]. Простолюдины обычно пользовалось традиционным жилищем, которое называлось түлгэ хана.

Решетчатая стена традиционного жилища обычно скрепляется между собой с помощью калм., ойр. М $ү \partial ә р$ 'крепление (в виде тонких кожаных ремней)', х.-монг. Удээр 'тонкие кожаные ремни (для скрепления составных частей решётчатой стены юрты; для прикрепления седельных досок к луке и т. д.)'. Например, хадын үдэр 'ременное скрепление жердей решёток стен юрты в месте соединения', бур. үдөөри 'ремешки для пристегивания (или прикрепления), кожаный шнур', ханын үдөөри (ханын модонуудые холбоходо үдэдэг, түүхэй арһа зүһэжэ хэһэннарин таһама 'кожаные тесемки для скрепления реек стенки юрты') или ханын үдөөри зангиланууд (hyp maha- мыль нэгэ ҮзҮҮрыень нүхэлөөд, тэрэ нүхөөр нүгөө ҮзҮҮрыень гулдируулан оруулаад, ханын модонуудай нүхэнүҮдээрнь зосоо талаһаань гаргажа зангидадаг 'кляпики на обеих сторонах стенных реек, чтобы тесемки не выдергивались') [Шагдаров, Черемисов, II 2010: 393], стпм. ӥderi 'тонкие кожаные ремни' (для скрепления составных частей решетчатой стены юрты, для прикрепления седельных досок к луке и т. д.) [БАМРC, 3 2001: 391].

В комплект обрешетки калм., ойр.М герин модн 'деревянный остов' входит несколько десятков жердей, обычно более 70, которые выполняют функцию стропил, х.монг. гэрийн араг мод 'деревянный остов юрты' [КРС 1977: 138], бур. hэеы гэрэй модон id. [Шагдаров, Черемисов, I 2010: 240].

калм., ойр.М уньн 'унина, жердь (которой поддерживается верхний круг юрты)', например, унь зүYх 'вставить жердь (в отверстие верхнего края юрты)', х.-монг. унь 'жердь (на которой поддерживается верхний круг юрты); своеобразные стропила (поддерживающие кровлю войлочной юрты); остов; обрешетка', например, гэрийн унь ‘жерди юрты’; унь өлгөх ‘вставить жердь в отверстие верхнего круга и закрепить ее в головках решетчатой стены'; унины үххр 'пазы в дымовом круге, в которые вставляются верхние концы 'уни' [БАМРС, 3 2001: 338], бур. уняа 'стропила (для юрты: своеобразные стропила, поддерживающие кровлю войлочной юрты и верхний ее круг)', стпм. uni/unin id. [БАМРС, 3 2001: 337].

Традиционное жилище гер состоит из двух кругов. Нижний круг или основание гер состоит из деревянных решетчатых стен в форме цилиндра, а верхний круг представляет форму тупого конуса:

калм., ойр.М харач 'матица, круг (юрты)': харач өндәхлд, өрк чигн өндәдг 'когда поднимется матица кибитки, то поднимется и семья', в проклятии в чей-л. адрес харачнь хамхртха уст. 'да поломается матица его юрты!' [КРС 1977: 578], х.-монг. тооно '1) тон (круг верхнего отверстия юрты); дымовой круг юрты (через отверстие которого выходит дым)': тооно босгох 'открывать домовой круг', бур. тооно 'отверстие в крыше юрты, дымовой круг’ (круг верхнего дымового отверстия юрты с поперечной и отходящими от нее радиальными спицами, на которые накладывалась для закрывания 
войлочная шестиугольная крышка $ү р x \ni)$ : тооноор утаан бурьяна 'через отверстие в крыше клубится дым', тооноо maтаха (нээхэ) 'открывать домовой круг (потянув за волосяную веревку)', стпм. to ono [БАМРС, 3 2001: 213].

Верхний круг традиционного жилища гер представляет собой деревянный круг, сделанный, как пишет У. Э. Эрдниев, «из отдельных (от 4 до 15, иногда больше) березовых дуг» [Эрдниев 1970: 127].

В верхней части каждой тэрэм делали по 10-18 гнезд, которые носили название: калм. термин тольа 'верхние концы решетки кибитки’, х-монг. ханын толгой, бур. ханын тархи 'верхние концы решетчатых стенок юрты', к которым прикреплялись при помощи кожаных ремешков из верблюжьей шерсти или конского волоса: калм., ойр.М уньна салдрh 'ремённая застежка', х.-монг. унийн сагалдрага 'петля, застежка у жерди (юрты)', бур. һагалдарга, стпм. ипіn-и sayaldurya id [БАМРC, 3 2001: 67].

В основе круглого верха традиционного жилища находится четыре полуобруча калм., ойр.М ияһррг 'перекладина-крестовина, поперечина дымника юрты': ишкә герин харач деер кирсләд тәвсн нәрхн модд 'на верху дымника войлочной юрты закреплены тонкие крест накрест жердины', х.-монг. цагариг '1. обруч, кольцо; круг, кружок, колесо; обод', бур. сахариг 'обруч, обод, ободья’, стпм. čayariy id [БАМРС, 4 2002: 244].

Через круг верхнего отверстия жилища проникает свет, и через него же выходит дым, например, калм., ойр.М өрк. 'ІІ. дымовое отверстие (в крыше кибитке), дымоход, дымник; II. четырехугольная кошма (прикрывающее дымовое отверстие в кибитке)'.

У. Э. Эрдниев пишет, что эта кошма представляет собой 4 угла или конца длиной 60-65 сантиметров [Эрдниев 1970: 128]; х.-монг. өрx(өн) 'четырехугольная кошма, прикрывающее дымовое отверстие (дымник) юрты; покрывало дымника', бур. үрхэ «'1) дымовое отверстие (в крыше юрты), дымник; кошма, прикрывающая дымник'», стпм. erüke [БАМРС, 3 2001: 44].

К концам этой четырехугольной кошмы прикрепляются четыре волосяные тесьмы, которые называются: калм. бүч 'шнур, тесьма; лента'; в калмыцком эпосе властелину страны Бумба Джангару ооср бүч уга ор ияаган өркә харһв 'встретился одинокий белый дворец без тесьмы и привязок', х.-монг. хоилон (дээс) 'толстая тесьма, стяжка, которой опоясывается юрта; волосяная веревка', гэрийн хошлон 'опоясывающая юрту тесьма', бур. хошлон 'волосяные веревки', стпм. qošilang id. [БАМРС, 4 2002: 122].

Для укрепления жилища внутри него ставили два столба для поддержания верхнего каркаса: калм., ойр.М бахн 'столб, колонна; опорная балка', х.-монг. багана 'столб, столп, колонна, подпорка (на которую опирается юрта, палатка)', бур. багана 'столб, колонна; подпорка, подставка', стпм. bayana id. [БАМРС, 1 2001: 208].

Дверной проем по-калмыцки называется күңкрә 'дверная часть (в решетке кибитки)', это же слово находим и в языке ойратов Монголии, х.-монг., бур. хүнхрээ 'прилегающие к двери части решетчатой стены юрты' (обычно устанавливается между первой и последней решетчатыми стенами), стпм. küngger-e id. [БАМРС, 4 2002: 289].

Дверной проем состоял из калм. тотx 'притолока, косяк (двери)', это слово зафиксировано в загадке тотх деер тоһшин өрәл 'на косяке двери половина кренделя' с отгадкой луна, х.-монг. тотго 'притолока', бур. тотого 'притолока, косяк (двери)', стпм. toto $о$ [БАМРС, 3 2001: 233].

В дверной проем также входил эркн калм., ойр.М 'порог', х.-монг. эрхин 'порог', бур. эрхин 'дверная колода' в значении 'нижний косяк, порог юрты'. Кстати, в бурятской литературе имеются сведения о посвящении-инициации мальчиков у порога юрты: эрхиндэхи улаан хурьган (досл. 'рыжий ягненок у косяка двери') [Шагдаров, Черемисов, II 2010: 673]; стпм. erkin id, следует отметить, что нами зафиксирован синонимичный термин: калм., ойр.М босха, х.-монг. босго, бур. богоһо, стпм. bоsuүa в значении «порог», высота которого обычно 20 см от земли [Шагдаров, Черемисов, II 2010: 549].

Далее термин 'дверь' - это одна из основных частей жилища, например, калм. $x a$ свчта $ү Y$ 'н 'створчатая дверь (калмыцкой кибитки)', этот термин встречается в калмыцком эпосе: мөңзгн хасвчинь жсиниүлжс татад, барун эркнднь суув '[Джангар], открыв серебряную двустворчатую дверь, сел у двери с правой стороны кибитки', х.-монг. хавтастай $Y Y$ 'створчатая дверь юрты', 


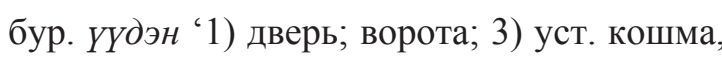
закрывавшая вход в юрту', стпм. egüden. По обычаю у некоторых монгольских народов дверь, как правило, обращена на юг или юго-восток.

После установки жилища его покрывают войлоком, который назывался: калм., ойр.М деевр, например: хальмг герин ишкә деевр 'верхнее кошмовое покрывало калмыцкой кибитки', деевр ишкә делкә бүтәжс (загадка) 'верхнее кошмовое покрывало закрывало весь мир' (отгадка - цасн 'снег') [КРC 1977: 193].

В словаре со ссылкой на эпос «Джангар» встречаем: барсин арсар дееврлгсн Бумбин цаһан өргә делдүләд нутган иуглуль '[Джангар], возведя белый дворец Бумбы, крытый шкурами барсов, начал собирать свой народ и восстанавливать державу свою' [КРС 1977: 193], х.-монг. дээвэр, бур. дээбэри, 'войлочное покрывало (верхней части кибитки)’ [КРС 1977: 193].

Как правило, таких покрытий было четыре с общим названием: калм. myуph, х.монг. mуурга, бур. mуурга, стпм. tuүurүa 'войлочные стены'. В калмыцком языке, как отмечает У. Э. Эрдниев, каждое турго имело особое название: барун турго 'правое турго', зүн турго 'левое турго', көл турго 'ножное турго', деер турго 'верхнее турго'; далее прикреплялась так называе-

\section{Сокращения}

бур. - бурятский язык

калм. - калмыцкий язык

\section{Полевой материал авторов}

ПМА 2018 - Пурэвжавын Мягмар, 1941 г. p. Запись в сумоне Давст (Увсунурский аймак, Монголия), 2018 г.

\section{Литература}

Бобровников 1835 - Бобровников Александр. Грамматика монгольского языка, сочиненная Протоиереем Иркутской Епархии Александром Бобровниковым. СПб.: Тип. Святейшего правительствующего Синода, 1835 $128 \mathrm{c.}$

Бобровников 1849 - Бобровников Алексей. Грамматика монгольско-калмыцкого языка. Казань: Типо-лит. Имп. ун-та, 1849. 403 с.

БАМРС, 12001 - Большой академический монгольско-русский словарь: в 4 т. Т. 1. А-Г /

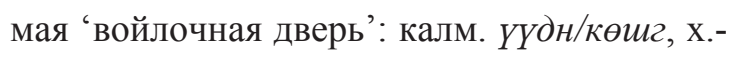
монг. гэрийн хөшиг, бур. һэеьл ҮYдэн, стпм. köšige; в конце поднималось войлочное покрытие: калм. өрк, х.-монг. өрх, бур. үрхэ, стпм. erüke, которое закрывало дымовое отверстие.

\section{Выводы}

Приведенный обзор названий традиционного жилища и его частей у калмыков и ойратов Монголии (для сравнения приводился материал из халха-монгольского, бурятского и старописьменного монгольского языков) на предмет выявления терминов общемонгольского характера [Рассадин, Трофимова, Шагдарсурэн, Болд, Даваасурэн 2010: 143], специфических терминов, которые характерны для калмыцкого и языка ойратов Монголии, показывает большое разнообразие названий, которые созданы этими народами в течение их исторического развития. Все термины представлены в старописьменном монгольском языке.

Эта лексика активно и широко используется в языке ойратов, современном халха-монгольском языке в отличие от бурятского и тем более от калмыцкого языков, поскольку некоторая их часть до сих пор пользуется войлочными юртами как стационарным жилищем, так и транспортируемым жилищем при перекочевке на летние пастбища.

ойр.М - ойратский Монголии

х.-монг. — халха-монгольский язык

стпм. - старописьменный монгольский язык

\section{Author's Field Data}

Informant: Purevzhavyn Myagmar, b. 1941. Rec. in Davst (Uvs Province, Mongolia), 2018. (Oir.)

отв. ред. Г. Ц. Пюрбеев. М.: Academia, 2001. $486 \mathrm{c}$.

БАМРС, 22001 - Большой академический монгольско-русский словарь: в 4 т. Т. 2. Д-О / отв. ред. Г. Ц. Пюрбеев. М.: Academia, 2001. $507 \mathrm{c}$.

БАМРС, 32001 - Большой академический монгольско-русский словарь: в 4 т. Т. 3. Ө-Ф / отв. ред. Г. Ц. Пюрбеев. М.: Academia, 2001. $438 \mathrm{c.}$

БАМРС, 42002 - Большой академический монгольско-русский словарь: в 4 т. Т. 4. Х-Я / 
отв. ред. Г. Ц. Пюрбеев. М.: Academia, 2002. $501 \mathrm{c}$.

Бальжинимаева 2018 - Бальжинимаева Б. Д. Традиционная ремесленная лексика в монгольских языках: сравнительно-исторический аспект. Элиста: ЗАОр НПП «Джангар», 2018. 198 c.

Бальжинимаева 2006 - Бальжинимаева Ц. Ц. О некоторых названиях предметов материальной культуры в тункинском говоре бурятского языка // Монгольские языки и диалекты северо-восточного ареала Центральной Азии. Улан-Удэ: Изд-во БНЦ СО РАН, 2006. C. 111-123.

КРС 1977 - Калмыцко-русский словарь / под ред. Б. Д. Муниева. М.: Русский язык, 1977. $765 \mathrm{c}$.

Мазарчук 2017 - Мазарчук А. В. Лексика по разделу «швейное производство» в монгольском языке // Сетевое востоковедение: образование, наука, культура. Мат-лы междунар. науч. конф. (г. Элиста, 7-10 декабря 2017 г.). Элиста: Изд-во Калм. ун-та, 2017. C. $125-128$.

Материалы по истории 1968 - Материалы по истории сюнну (по китайским источникам) / предисл., перев. и прим. В. С. Таскина; отв. ред. Л. И. Думан. М.: Наука, ГРВЛ, $1968.177 \mathrm{c}$.

Попов 1847 - Попов А. Грамматика калмыцкого языка. Казань: Типо-лит. Имп. ун-та, 1847. $392 \mathrm{c}$.

Пюрбеев 1996 - Пюрбеев Г. Ц. Толковый словарь традиционного быта калмыков. Элиста: Калм. кн. изд-во, 1996. 176 с.

Рассадин, Трофимова, Чулуунбаатар 2017 Рассадин В. И., Трофимова С. М., Чулуунба-

\section{References}

Balzhinimaeva B. D. Traditional Handicraft Vocabulary of Mongolic Languages: A Comparative Historical Perspective. Elista: Dzhangar, 2018. 198 p. (In Russ.)

Balzhinimaeva Ts. Ts. Tunka dialect of Buryat: some names of cultural artifacts revisited. In: Mongolic Languages and Dialects of Northeastern Central Asia. Ulan-Ude: Buryat Scientific Center (Sib. Branch of RAS), 2006. Pp. 111-123. (In Russ.)

Bobrovnikov A. Grammar of Kalmyk Mongolian. Kazan: Imperial Kazan University, 1849. 403 p. (In Russ.)

Bobrovnikov A. Grammar of Mongolian by Ven. Aleksandr Bobrovnikov, Protoiereus of Irkutsk атар Л. Общемонгольская лексика по разделу «традиционное жилище» в халхаском, бурятском и калмыцком языках // Вестник Калмыцкого института гуманитарных исследований. 2017. № 4 (32). С. 134-140.

Рассадин, Трофимова, Шагдарсурэн, Болд, Даваасурэн 2010 - Рассадин В. И., Трофимова С. М., Шагдарсурэн Ц., Болд Л., Даваасурэн Б. Историческая связь калмыцкого языка с языком ойратов Монголии. Элиста; Улан-Батор: Изд-во Калм. ун-та, 2010, 182 с. Трофимова, Даваасурэн 2017 - Трофимова С. М., Даваасурэн Б. Общемонгольская лексика по разделу «традиционная пища» в халха-монгольском, бурятском и калмыцком языках (на материале кулинарных рецептов) // Известия Волгоградского государственного педагогического университета. 2017. № 10 (123). С. 133-136.

Шагдаров, Черемисов, I 2010 - Шагдаров Л. Д., Черемисов K. M. Буряад-ород толи. Бурятско-русский словарь. Т. І. Улан-Удэ: Респуб. тип., 2010. $636 \mathrm{c.}$

Шагдаров, Черемисов, II 2010 - Шагдаров Л. Д., Черемисов К. М. Буряад-ород толи. Бурятско-русский словарь. Т. ІІ. Улан-Удэ: Респуб. тип., 2010. 708 с.

Шмидт 1832 - Шмидт Я. И. Грамматика монгольского языка / пер. с нем. СПб.: Тип. Имп. Акад. наук, 1832. 184 с.

Эрендженов 1990 - Эрендженов К. Э. Золотой родник: о калмыцком народном творчестве, ремесле и быте / пер. с калм. А. Аквилева. 2-е изд. Элиста: Калм. кн. изд-во, 1990. 125 с. Эрдниев $1970-$ Эрдниев У. Э. Калмыки (конец XIX - XX вв.). Историко-этнографические очерки. Элиста: Калм. кн. изд-во, 1970. 312 с.

Eparchy. St. Petersburg: Most Holy Governing Synod, 1835. 128 p. (In Russ.)

Duman L. I. (ed.) Materials in Xiongnu History: Excerpts from Chinese Sources. V. Taskin (foreword, transl. etc.). Moscow: Nauka - GRVL, 1968. 177 p. (In Russ.)

Erdniev U. E. The Kalmyks, Late $19^{\text {th }}-20^{\text {th }}$ Centuries: Essays in History and Ethnography. Elista: Kalmykia Book Publ., 1970. 312 p. (In Russ.)

Erendzhenov K. E. The Golden Spring. Zolotoy rodnik: Kalmyk Folklore, Handicrafts, and Traditional Household Activities. A. Akvilev (transl.). $2^{\text {nd }}$ ed. Elista: Kalmykia Book Publ., 1990. 125 p. (In Russ.)

Mazarchuk A. V. Clothing production related vocabulary of Mongolian. In: Network Oriental 
Studies — Education, Science, Culture. Conference proceedings (Elista; December 7-10, 2017). Elista: Kalmyk State University, 2017. Pp. 125-128. (In Russ.)

Muniev B. D. (ed.) Kalmyk-Russian Dictionary. Moscow: Russkiy Yazyk, 1977. 765 p. (In Kalm. and Russ.)

Popov A. Kalmyk Grammar. Kazan: Imperial Kazan University, 1847. 392 p. (In Russ.)

Pyurbeev G. Ts. (ed.) Unabridged Academic Mongolian-Russian Dictionary. In 4 vols. Vol. 1: A-Г. Moscow: Academia, 2001. 486 p. (In Mong. and Russ.)

Pyurbeev G. Ts. (ed.) Unabridged Academic Mongolian-Russian Dictionary. In 4 vols. Vol. 2: Д-О. Moscow: Academia, 2001. 507 p. (In Mong. and Russ.)

Pyurbeev G. Ts. (ed.) Unabridged Academic Mongolian-Russian Dictionary. In 4 vols. Vol. 3: Ө-Ф. Moscow: Academia, 2001. 438 p. (In Mong. and Russ.)

Pyurbeev G. Ts. (ed.) Unabridged Academic Mongolian-Russian Dictionary. In 4 vols. Vol. 4: X-Я. Moscow: Academia, 2002. 501 p. (In Mong. and Russ.)

Pyurbeev G. Ts. Traditional Household Activities of the Kalmyks: An Explanatory Dictionary. Elista: Kalmykia Book Publ., 1996. 176 p. (In Kalm. and Russ.)
Rassadin V. I., Trofimova S. M., Chuluunbaatar L. The Khalkha Mongolian, Buryat and Kalmyk languages: common Mongolian lexis denoting the traditional home. Bulletin of the Kalmyk Institute for Humanities of the RAS (Oriental Studies) Vestnik Kalmytskogo instituta gumanitarnykh issledovaniy. 2017. No. 4 (32). Pp. 134-140. (In Russ.)

Rassadin V. I., Trofimova S. M., Shagdarsuren Ts., Bold L., Davaasuren B. Kalmyk (Russia) and Oirat (Mongolia): Historical Linguistic Ties Reviewed. Elista, Ulaanbaatar: Kalmyk State University, 2010, 182 p. (In Russ.)

Schmidt J. I. Mongolian Grammar. St. Petersburg: Imperial Academy of Sciences, 1832. 184 p. (In Russ.)

Shagdarov L. D., Cheremisov K. M. Buryat-Russian Dictionary. Vol. I. Ulan-Ude: Respublikanskaya Tipografiya, 2010. 636 p. (In Bur. and Russ.)

Shagdarov L. D., Cheremisov K. M. Buryat-Russian Dictionary. Vol. II. Ulan-Ude: Respublikanskaya Tipografiya, 2010. 708 p. (In Bur. and Russ.)

Trofimova S. M., Davaasuren B. Mongolian vocabulary on the topic 'cooking recipes' in Khalkha Mongolian, Buryat and Kalmyk languages. Izvestia of the Volgograd State Pedagogical University. 2017. No. 10 (123). Pp. 133-136. (In Russ.) 